\title{
Islamic Terrorism as a THREAT TO THE Security of Eastern European Countries
}

\section{Introduction}

The purpose of the article is to assess the scale of Islamic terrorism threat in Eastern Europe ${ }^{2}$. In terms of geography, special attention was given to the region's two biggest countries - Russia and Ukraine. The time-frame of this article basically covers the period from 2014 to 2019 . However, certain threads refer to events that took place a decade earlier (in 2010). Taking up this topic seems well-based, as the threat of terrorism still remains a live issue (as proven by the statistics) and is at the centre of security policies of all the region's countries. Furthermore, terrorism as a method of operating, constantly evolves. Firstly, due to terrorists' efforts to increase their effectiveness, secondly due to objective geopolitical, social or technological changes ${ }^{3}$.

The main research question of this article is: to what extent does the activity of groups and individuals invoking radical Islam and adopting terrorist methods influence the security level of Eastern European countries? Specific research questions are as follows:

1. How does the phenomenon of terrorism in Eastern Europe evolve in the light of statistical data?

2. How did the threat from terrorist groups originating in North Caucasus evolve in the past decade?

3. What threats are posed to the territory of Eastern Europe by the Islamic State (further referred to as ISIS), and particularly by the so-called

1 Dr Tomasz Grabowski - assistant professor at the Institute of Political and Administrative Sciences of the Jesuit University Ignatianum in Krakow.

Correspondence address: <tomasz.grabowski@ignatianum.edu.pl>.

2 For the purpose of the article, Eastern Europe is understood as the territory of the following countries: Russia, Ukraine, Belarus, Moldova, Armenia, Azerbaijan, Georgia.

3 Cf. T.R. Aleksandrowicz, Kluczowe megatrendy w bezpieczeństwie państwa w XXI wieku, Warsaw, 2020. 
foreign terrorist fighters (further referred to as FTF) from post-Soviet region, recently fighting in the ranks of Middle East terrorist groupings?

\section{Eastern Europe Terrorism Index}

Probably the most quoted index in the research on terrorism is the Global Terrorism Index (GTI), prepared and published every year by the Institute of Economics \& Peace ${ }^{4}$. As for Eastern European countries, according to the GTI, the situation in terms of anti-terrorism security between 2014 and 2019 was dynamic and in certain cases brought considerable fluctuations. Only for Moldova, the terrorism index remained on a low level (see table 1 for full data).

Table 1

Eastern European countries in the Global Terrorism Index (GTI)

\begin{tabular}{|l|r|r|r|r|r|r|r|}
\hline Years & Armenia & Azerbaijan & Belarus & Georgia & Moldova & Russia & Ukraine \\
\hline 2014 & 0.27 & 0.06 & 2.85 & 2.58 & 0.28 & 6.76 & 2.95 \\
\hline 2015 & 0.115 & 1.81 & 2.125 & 2.373 & 0.038 & 6.207 & 7.2 \\
\hline 2016 & 0.288 & 0.346 & 1.357 & 1.257 & 0.019 & 5.43 & 7.132 \\
\hline 2017 & 2.374 & 1.153 & 0.038 & 2.114 & 0.47 & 5.329 & 6.557 \\
\hline 2018 & 1.692 & 0.957 & - & 1.422 & 0.229 & 5.23 & 6.048 \\
\hline 2019 & 1.173 & 0.698 & - & 1.335 & 0.115 & 4.9 & 5.547 \\
\hline
\end{tabular}

Source: Author's own study based on: Institute for Economics \& Peace, Global Terrorism Index 2014: Measuring and understanding the impact of terrorism, Sydney 2014; Institute for Economics \& Peace, Global Terrorism Index 2015: Measuring and understanding the impact of terrorism, Sydney 2015; Institute for Economics \& Peace, Global Terrorism Index 2016: Measuring and understanding the impact of terrorism, Sydney 2016; Institute for Economics \& Peace, Global Terrorism Index 2017: Measuring and understanding the impact of terrorism, Sydney 2017; Institute for Economics \& Peace, Global Terrorism Index 2018: Measuring the impact of terrorism, Sydney 2018; Institute for Economics \& Peace, Global Terrorism Index 2019: Measuring the Impact of Terrorism, Sydney 2019

4 The index is created on the basis of information about the number of terrorist acts, the number of fatalities and non-fatal casualties, as well as financial losses they brought - during the 5 years before the publication of the index for a given year (whereas the last year is of highest importance for the final index). The final score falls within the range of $1-10$, where 10 means the highest terrorist threat, and 0 the lowest (for example, in 2017 Iraq scored 10, and Lithuania - 0). 
As far as Eastern Europe is concerned, the most striking tendency, noticeable thanks to the research of GTI reports' authors, is the rise in terrorism threat level in Ukraine. In 2015, Ukraine ranked higher in the terrorism index than Russian Federation, which for many years had been the region's leader in this respect (chart 1). In any case, it was one of the highest growths of terrorism indices in the world. Between 2000 and 2013, only 3 people were killed as a result of terrorist attacks in Ukraine, in 2013 itself the number of fatalities was 0, but already in 2014, the number was as many as $665^{5}$. Such a growth of the threat was naturally the result of the conflict between Russia and Ukraine, where the Russian side adopted "hybrid" methods, consisting in using unofficial forces and measures. According to the authors of the GTI, shooting down the Malaysian airlines plane in the Donbas region, which cost the lives of 298 people, was, in terms of the number of fatalities, the fifth attack in the world in $2014^{6}$. In 2015, Donetsk and Odessa were in the top ten cities with the highest number of people killed as a result of a terrorist attack per 100 thousand inhabitants (in $5^{\text {th }}$ and 8 th place respectively ${ }^{7}$ ). Terrorist methods are used during the conflict in the east of Ukraine both by pro-Russian separatists, and by Ukrainian forces, which are probably responsible for assassinating Donetsk leaders (Arsen Pavlov aka "Motorola", Aleksandr Zakharchenko and others) in bomb attacks. In fact, the matter at hand here is state terrorism (inspired, supported, or at least tolerated by the state). In the years following the downing of the passenger plane belonging to Malaysia Airlines, the terrorism index in Ukraine dropped, but nonetheless remained relatively high (highest in the region) until 2019.

In case of Russia, a noticeable tendency is the gradual decrease in terrorism threat level. Scoring 4.9 in 2019 was Russia's lowest rank in the index since the Institute of Economics \& Peace had started publishing its research. Effective counterterrorism policy in the North Caucasus certainly helped to improve the country's situation. Nevertheless, Russia's terrorism index still remains on a level that could be deemed disturbing, and the socio-political situation in the North Caucasus definitely does not allow to state that the threat of Islamic and separatist radicalism belongs here to the past (to be discussed further in the article).

5 Institute for Economics \& Peace, Global Terrorism Index 2015: Measuring and understanding the impact of terrorism, Sydney 2015, p. 16.

6 Ibidem, p. 93.

7 Ibidem, p. 31. 
Belarus, Russia and Ukraine in the Global Terrorism Index (GTI)

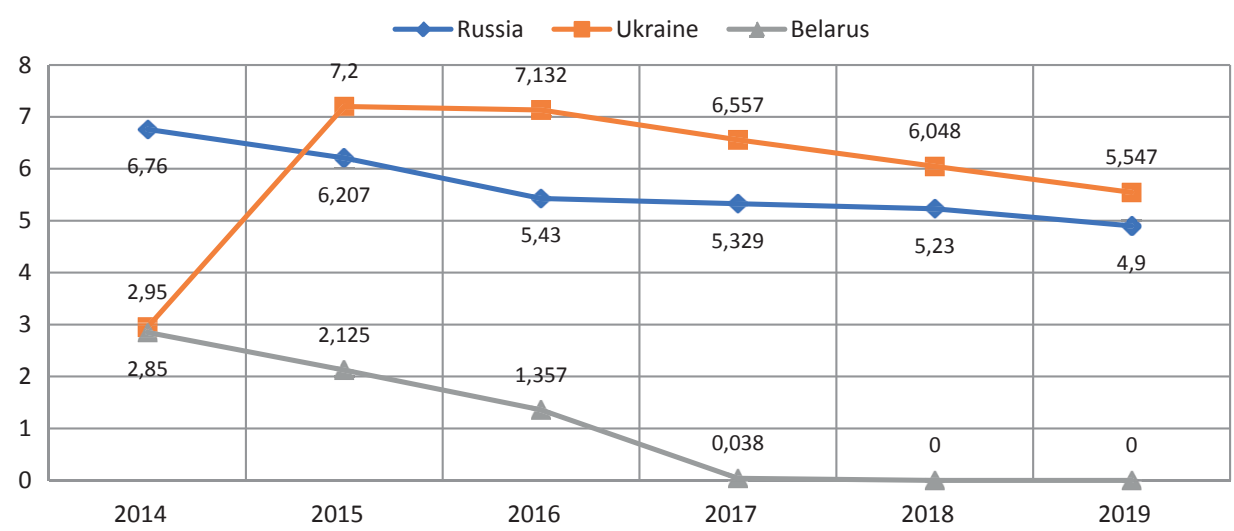

Source: Author's own study based on: Institute for Economics \& Peace, Global Terrorism Index 2014..., op. cit.; Institute for Economics \& Peace, Global Terrorism Index 2015..., op. cit.; Institute for Economics \& Peace, Global Terrorism Index 2016..., op. cit.; Institute for Economics \& Peace, Global Terrorism Index 2017..., op. cit; Institute for Economics \& Peace, Global Terrorism Index 2018..., op. cit.; Institute for Economics \& Peace, Global Terrorism Index 2019..., op. cit.

An even more downward trend can be observed in Belarus. As far as this country is concerned, the most tragic year in terms of antiterrorism security was 2011, when there was an attack in the Minsk underground, killing 15 people and leaving 204 injured. In 2012 there were a few notorious incidents, such as: explosion of a charge at a border crossing between Belarus and Poland, Molotov cocktail attack on the Lithuanian embassy in Minsk, or the explosion near State Security Committee building in Vitebsk. However, the scale of these incidents was incomparable with what was happening in Russia at that time, or in Ukraine during the few years that followed. During the following years, the terrorist threat level in Belarus decreased significantly. Two perpetrators of the 2011 Minsk attack were sentenced to death after a short trial, and - despite controversy ${ }^{8}$ and protests - executed by firing squad as early as in March 2012. It demonstrated Belarussian authorities' severity with regard to fighting terrorism. According to the Institute of Economics \& Peace, the terrorism threat level in Belarus in 2017 was minimal, and in the two following years $(2018$, 2019), the terrorism index was equal to zero. The threat level in Belarus will not probably change in the nearest future, because the country remains outside the main processes shaping the phenomenon of terrorism in Eastern Europe (such as, for example, the movements of radical foreign

8 According to an independent poll conducted in 2011 , as many as $43 \%$ of interviewees in Belarus do not believe the official version of events related to the attack and the results of investigation, whereas 37\% do not agree with the authorities' conclusions. As cited in: И. Кумей, Кто устроил теракт в минском метро?, <https:// belsat.eu/ru/programs/kto-ustroil-terakt-v-minskom-metro>, 29 July 2020. 
terrorist fighters). Obviously, isolated, politically motivated acts of terrorism can never be ruled out, but the probability of their occurrence is low.

As far as the South Caucasus region is concerned, the terrorism threat level according to the Global Terrorism Index is low or very low (Chart 2). In the past, the region was many a times the arena of terrorist activity, related mainly to interstate, intrastate (political), nationalist and separatist conflicts. In the recent period (after 2014), the biggest threat has been posed by religiously motivated terrorists ${ }^{9}$.

Chart 2

\section{South Caucasus countries in the Global Terrorism Index}

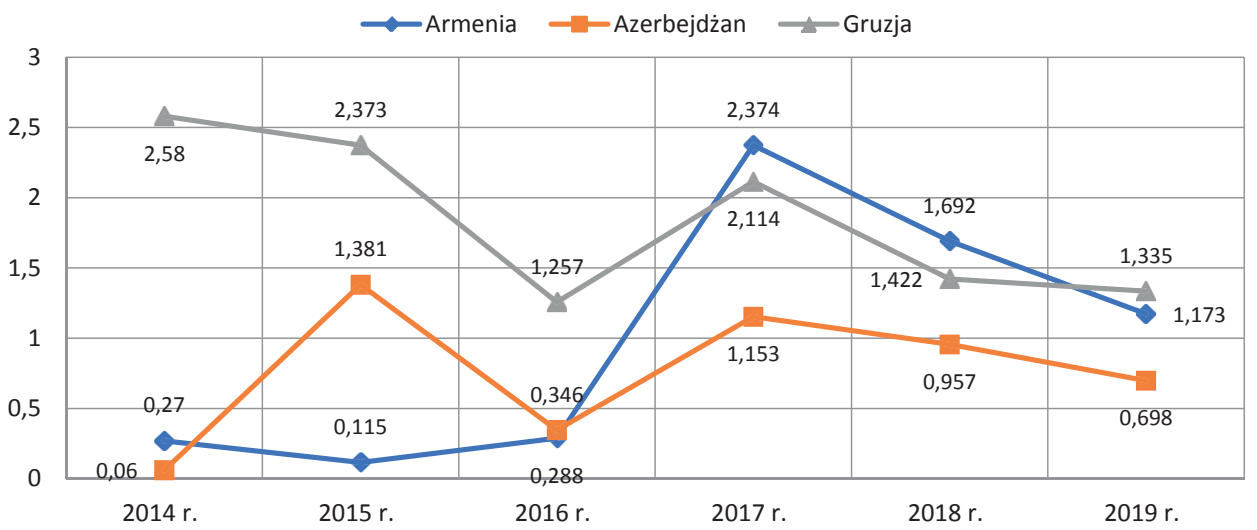

Source: Author's own study based on: Institute for Economics \& Peace, Global Terrorism Index 2014..., op. cit.; Institute for Economics \& Peace, Global Terrorism Index 2015..., op. cit.; Institute for Economics \& Peace, Global Terrorism Index 2016..., op. cit.; Institute for Economics \& Peace, Global Terrorism Index 2017..., op. cit.; Institute for Economics \& Peace, Global Terrorism Index 2018..., op. cit.; Institute for Economics \& Peace, Global Terrorism Index 2019..., op. cit.

In case of Georgia, a negative influence in this respect is exerted by such factors as: destabilisation caused by Russia taking over Abkhazia and South Ossetia and the processes occurring within these territories, deployment of Wahhabi groups in different regions of the country (Pankisi Gorge, Abkhazia), Georgia's participation in the international anti-terrorist coalition and various missions connected therewith. Another significant factor is the country's geostrategic location, making it a convenient place for different forms of terrorist activity (organising the transfer of terrorists from Russia and Central Asia to Syria, creating training bases and organising safe houses where terrorists coming back from the Middle East could hide, organising recruitment and conducting activities in terms of terrorism funding). However, Georgian services claim that the situation has significantly improved in the recent years. According to 2019 report, in the previous year (2018) there was

9 Г. Гикашвими, Терроризм на Южном Кавказе, Постсоветские исследования, 2019, Vol. 2, No. 5, pp. 1292-1299. 
a significant decrease in the number of attempts at using Georgia's territory to transfer persons connected with terrorism, and people who want to cross the border are thoroughly checked and monitored at border points ${ }^{10}$. Slightly earlier in 2019, Georgian government approved the "National counter-terrorism strategy" for the years 2019-2021, where it emphasised that the main threat to the country was the ISIS, as well as its fighters and followers. Second come the Al-Qaida and the Taliban (in relation to Georgia's participation in "Resolute Support" mission in Afghanistan). The document also states that the number of ISIS supporters in Georgia was consequently decreasing thanks to the efforts of the secret service ${ }^{11}$. In the summative assessment, this record is definitely to be agreed with. Despite its difficult geostrategic location and unfavourable trends, both within and outside the country, Georgia was able to bring the terrorist threat to a relatively low level (as proven by GTI ranking), avoid attacks and actively react to the emerging challenges.

Among the region's countries, Armenia is probably the least threatened by Islamic terrorism. It is the result of the fact that the citizens of this Christian country do not participate in the Middle East fighting, and there are no dangers related thereto, such as the return of radicalised fighters. There is almost no Muslim population within the territory of Armenia, thus there is no risk that people will be inculcated with radical Islamic ideology ${ }^{12}$. What could destabilise the situation in Armenia is naturally the conflict with Azerbaijan, whose actions bear the hallmark of terrorism according to Armenians.

Whereas in case of Azerbaijan, there is a significantly low terrorism index, which exceeded the value of 1.0 only in 2017. It is definitely evidence of Azeri anti-terrorist system's high efficiency. A positive assessment of Azeri authorities' actions can, for instance, be found in American yearly Country Reports on Terrorism ${ }^{13}$. These are definitely objective assessments. Azeri services were able to identify approx. 900-1,000 citizens who had joined the ranks of the ISIS (approximately 100 of them were sentenced after coming back). Whereas the number of people who still make attempts to leave for Syria and Iraq has decreased significantly ${ }^{14}$. However, these

10 Sputnik, Террористы все реже используют Грузию для транзита отчет Службы госбезопасности, <https://sputnik-georgia.ru/georgia/2019042 2/245015484/terroristy-vse-rezhe-ispolzuyut-gruziyu-dlya-tranzita---otchet-slu zhby-gosbezopasnosti.html>, 29 July 2020.

11 ГРУЗИНФОРМ, Правительство Грузии утвердило Национальную стратегию по борьбе с терроризмом на 2019-2021 годы, разработанную межведомственной комиссией во главе со службой госбезопасности Грузии, <h ttp: / / ru.gruzinform.ge/news/39383/pravitelistvo-gruzii-utverdilo-nacionalinuU-s trategiU-po-boribe-s-terrorizmom-na-2019-2021-godi-razrabotannuU-meZvedoms tvennoj-komissiej-vo-glave-so-sluZboj-gosbezopasnosti-gruzii.html>, 29 July 2020.

12 Cf. Р. Мартиросян, Для Армении угрозой терроризма является не ИГИА, а Азербайджан, <https://inosmi.ru/politic/20170829/240132450.html>, 29 July 2020.

13 United States Department of State Publication, Country Reports on Terrorism 2018, October 2019, p. 74-76.

14 Sputnik, Борьба с терроризмом в Азербайджане дает свои плоды Кямиль Салимов, <https://az.sputniknews.ru/expert/20191106/422236799/ azerbaijan-terrorizm-usa.html>, 29 July 2020. 
data prove that the level of radicalisation in such a small country as Azerbaijan is high and poses a huge threat to its security. On the other hand, the past experience shows that Azeri services can neutralise this threat.

\section{Terrorism in the Russian North Caucasus}

For a relatively long time, terrorism in Eastern Europe related mainly to the activities of Chechen, or - broadly speaking - North Caucasian groups $^{15}$. The conflict in this most southern region of Russia was considered the bloodiest one in Europe, before the outbreak of war in Ukraine. Attacks and fights between the terrorist underground and federal, as well as regional forces in the peak period (2009-2011) were causing approximately 750 fatalities per year. However, during the following decade, the landscape of anti-terrorist security in the North Caucasus changed radically, as proven by the data related to the number of fatalities in this region collected by Caucasian $K_{n o t}{ }^{16}$ website, administered by Russian Association Memorial (Chart 3).

Chart 3

Number of fatalities and non-fatal casualties on all sides of the conflict (fighters, siloviki, civilians) in the North Caucasus between 2010 and 2019.

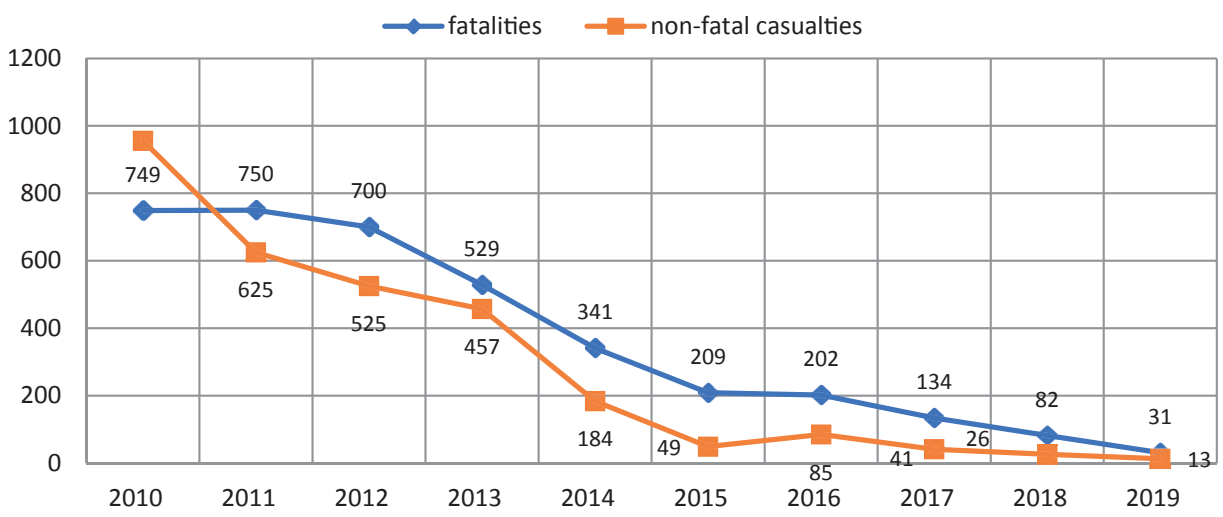

Source: Own study based on: Кавказский Узец, Северный Кавказ - статистика жертв, <https://www.kavkaz-uzel.eu/rubric/1103?page=1>, 29 July 2020.

15 North Caucasus is here understood as a territory of the North Caucasian Federal District of Russia, containing the following federal subjects: Chechnya, Dagestan, Ingushetia, Kabardino-Balkaria, North Ossetia - Alania, Karachay-Cherkessia, Stavropol Krai.

16 Кавказский Узел, Северный Кавказ - статистика жертв, <https:// www.kavkaz-uzel.eu/rubric/1103?page=1>, 29 July 2020. 
The situation was reversed by Russia's effective counter-terrorism strategy and by international conditions, i.e. outbreak of the civil war and proclamation of the ISIS in Syria. This country became the destination of North Caucasian volunteers, getting there through different channels and means. They were governed by sheer calculation: the probability of surviving the fights in the ranks of ISIS is much bigger than in the North Caucasus, where the Russian forces have huge dominance and ruthlessly eliminate terrorist cells. Obviously, the volunteers leaving for the Middle East were also motivated by religious factors and the will to fight in the world's most important jihadist front. According to the findings of the Centre for Research and Evidence on Security Threats, based on information from North Caucasian regional authorities, until the spring of 2017, the biggest number of volunteers left for Syria from Dagestan $(1,200)$ and Chechnya (600). Less volunteers left Ingushetia (200), Kabardino-Balkaria (175) and Karachay-Cherkessia (150) ${ }^{17}$. In total, it is 2,300 fighters. Other reports indicate that the number of volunteers from that region was much bigger.

The outflow of potential fighters caused the reduction of human resources in the North Caucasian terrorist underground, and the Caucasian Emirate, active since 2007, stopped being an attractive terrorist "brand" in the eyes of fighters, in comparison with the Islamic State, which, at that time, scored military and propaganda successes. In December 2014, the commander of one of Dagestani terrorist cells, pledged allegiance to the leader of the ISIS - Abu Bakr al-Baghdadi, and was followed by other leaders. On 21 June 2015, an audio recording was posted on YouTube, presenting fighters pledging allegiance to al-Baghdadi on behalf of all the wilayahs (provinces) of the Caucasian Emirate. By the spring of 2017, North Caucasus terrorists, acting under the banner of the ISIS, conducted eight attacks in Dagestan and fought four times with security forces in Chechnya ${ }^{18}$. Despite fighters' public declarations, threats made through different channels, and taking responsibility for the terrorist attacks in the Caucasus, there does not seem to be a strong and effective integration - structural and organizational - between the ISIS and the terrorist underground in the North Caucasus. The conflict in this region is abating, as proven by statistics of victims on every side of the conflict, i.e. among the fighters, siloviki ${ }^{19}$ and civilians (Table 2).

17 M. Youngman, C. Moore, Russian-Speaking' Fighters In Syria, Iraq And At Home: Consequences And Context (Full Report), 2017, p. 8, <https://crestresea rch.ac.uk/resources/russian-speaking-fighters-full-report>, 27 May 2021.

18 Кавказский Узец, Выходиы с Кавказа в рядах ИГ (ИГИА), <https://www. kavkaz-uzel.eu/articles/251513/\#cont_3>, 29 July 2020.

19 siloviki-police/law enforcement. 
Table 2

Number of victims (fatalities and non-fatal casualties) on all sides of the conflict (fighters, siloviki, civilians) in the North Caucasus between 2010 and 2019.

\begin{tabular}{|c|c|}
\hline Years & $\begin{array}{c}\text { Number of victims (fatalities and } \\
\text { non-fatal casualties) }\end{array}$ \\
\hline 2010 & 1705 \\
\hline 2011 & 1375 \\
\hline 2012 & 1225 \\
\hline 2013 & 986 \\
\hline 2014 & 525 \\
\hline 2015 & 258 \\
\hline 2016 & 287 \\
\hline 2017 & 175 \\
\hline 2018 & 108 \\
\hline 2019 & 44 \\
\hline Total & 6688 \\
\hline
\end{tabular}

Source: Author's own study on the basis of" Кавказский Узел, Северный..., op. cit.

In the last 10 years, the number of victims (fatalities and non-fatal casualties) in the North Caucasus dropped by as many as $97.4 \%$. In the last 5 years (2015-219) — it dropped by 82.9\%, whereas during last year (2018-2019) - by 59.2\%. It leads to the conclusion that the situation in the North Caucasus in terms of direct terrorist threat is improving every year and the local militant groups are not able to reverse this trend due to a people shortage, i.e. the decrease in the number of young people willing to conduct terrorist activities within their region. Whereas this people shortage cannot be explained only by the outflow of radicalised young people to Syria. Such journeys have been much more difficult since, approximately, 2015-2016, due to the work of Russian services and thorough border control (earlier, the Russians did not particularly care about who was leaving, but about who was returning). Perhaps the Russian security forces are able to eliminate terrorist cells at an earlier stage (when their members get radical and organised) and apply legal solutions, instead of physical elimination that is later reported in the statistics. 
Table 3

Number of fighters killed in the individual subjects of the North Caucasian Federal District of Russia between 2010 and 2019.

\begin{tabular}{|c|c|c|c|c|c|c|c|c|c|c|c|}
\hline \multirow{2}{*}{$\begin{array}{l}\text { Subject of the } \\
\text { North Caucasian } \\
\text { Federal District } \\
\text { of Russia }\end{array}$} & \multicolumn{10}{|c|}{ Years } & \multirow{2}{*}{$\begin{array}{c}\text { Total } \\
\text { between } \\
2010 \\
\text { and } \\
2019\end{array}$} \\
\hline & 2010 & 2011 & 2012 & 2013 & 2014 & 2015 & 2016 & 2017 & 2018 & 2019 & \\
\hline Chechnya & 80 & 62 & 38 & 20 & 24 & 45 & 20 & 20 & 21 & 4 & 334 \\
\hline Dagestan & 176 & 173 & 231 & 171 & 163 & 97 & 112 & 38 & 27 & 9 & 1197 \\
\hline Ingushetia & 63 & 40 & 40 & 23 & 15 & 15 & 13 & 8 & 6 & 2 & 225 \\
\hline Kabardino-Balkaria & 25 & 80 & 80 & 72 & 44 & 10 & 12 & 1 & 5 & 9 & 338 \\
\hline North Ossetia-Alania & 2 & 1 & 4 & 2 & - & - & - & 4 & - & - & 13 \\
\hline Karachay-Cherkessia & 1 & 13 & 2 & 2 & - & 4 & - & 5 & - & - & 27 \\
\hline Stavropol Krai & 2 & 15 & 9 & 8 & 3 & 1 & 5 & 6 & 6 & 2 & 57 \\
\hline Total & 349 & 384 & 404 & 298 & 249 & 172 & 162 & 82 & 65 & 26 & 2191 \\
\hline
\end{tabular}

Source: Author's own study on the basis of Кавказский Узел, Северный..., op. cit.

Juxtaposing the number of people killed in the conflict on the side of fighters with those killed on the side of siloviki also gives interesting results (compare table 3 and 4). In 2010 this ratio was 10 (fighters killed) to 6 (siloviki killed). In 2011, which marked the highest number of fatalities and generally the most intense activities conducted by the North Caucasian terrorist underground, this ratio was 10 to nearly 8, which indicated the terrorists' ability to inflict losses upon the security forces in a relatively equal combat. Later years brought a significant change. In 2015 the ratio of killed fighters to killed siloviki was only 10 to 1 , and in $2019-10$ to 2 . This comparison shows how uneven the combat in the North Caucasus has been in the last 5-6 years. Increasingly weaker cells of the terrorist underground are not able to inflict major losses upon the security forces and are permanently and consequently eliminated by them during their counter-terrorism operations. Furthermore, there are no troops of "forest" fighters in the Caucasus anymore. Their cells are usually eliminated during operations in cities, in the suburbs and in villages (according to the scheme: encirclement of the building, assault, elimination of fighters).

As far as civilian casualties are concerned, naturally there has also been a decrease. Since 2010, civilians have actually constituted the smallest percentage of fatalities, even with a relatively large number of "soft" target attacks, i.e. unrelated to public offices, police stations or military units. North Caucasian terrorism is, among others, characterised by the fact that the majority of fatalities are the victims of confrontations between security forces and fighters, as well as "hard" target attacks. 
Table 4

Security forces officers and soldiers of the Russian Federation killed in the North Caucasus conflict between 2010 and 2019.

\begin{tabular}{|c|c|c|c|c|c|c|c|c|c|c|c|}
\hline \multirow{2}{*}{$\begin{array}{l}\text { Subcject of North } \\
\text { Caucasian Federal } \\
\text { District of Russia }\end{array}$} & \multicolumn{10}{|c|}{ Years } & \multirow{2}{*}{$\begin{array}{c}\text { Total } \\
\text { between } \\
2010 \\
\text { and } \\
2019\end{array}$} \\
\hline & 2010 & 2011 & 2012 & 2013 & 2014 & 2015 & 2016 & 2017 & 2018 & 2019 & \\
\hline Chechnya & 44 & 21 & 43 & 18 & 26 & 2 & 6 & 13 & 3 & 2 & 178 \\
\hline Dagestan & 124 & 211 & 110 & 88 & 21 & 13 & 22 & 5 & 3 & - & 597 \\
\hline Ingushetia & 31 & 19 & 33 & 6 & 4 & 1 & 2 & 3 & - & 2 & 101 \\
\hline Kabardino-Balkaria & 23 & 31 & 19 & 14 & 4 & 2 & 2 & - & 1 & 1 & 97 \\
\hline $\begin{array}{l}\text { North Ossetia- } \\
\text { Alania }\end{array}$ & 2 & - & 1 & - & - & - & - & 1 & - & - & 4 \\
\hline $\begin{array}{l}\text { Karachay- } \\
\text { Cherkessia }\end{array}$ & 1 & 6 & 3 & - & - & - & - & - & - & - & 10 \\
\hline Stavropol Krai & - & 2 & - & 1 & - & - & - & - & - & - & 3 \\
\hline Total & 225 & 290 & 209 & 127 & 55 & 18 & 32 & 22 & 7 & 5 & 990 \\
\hline
\end{tabular}

Source: Author's own study on the basis of Kavkaz-Uzel.ru. data

In 2010, the ratio of civilian to total fatalities in the North Caucasus was $23 \%$, in 2015 - only 9\%, whereas in 2019 - 0\%, because 2019 was the first year - since the Caucasian Knot had kept victim statistics without a single civilian fatality. Thus, the number of civilians killed between 2010 and 2019 decreased by 100\% (from 175 fatalities in 2010 to no fatalities in 2019), which makes 2019 a breakthrough year, transforming the general picture of security in the North Caucasus. Local groupings stopped being a threat for the region on the scale known in the past, and Russian counter-terrorism activities, consisting in eliminating terrorist cells and deterring potential terrorists, brought measurable effects. Currently, it is hard to forecast that the trend will quickly be reversed.

On the other hand, we must remember that as far as anti-terrorist security is concerned, the quantitative and statistical data referring to the past can be confounding, because a small, but well-organised terrorist group can conduct a single attack that might cause a large death toll and have a huge psychological effect. Are North Caucasian groups capable of conducting such an assault? There certainly is such a risk, although the last attack of this kind, which drew the world's attention, was the series of three assaults in Volgograd in October and December of 2013 (in total, 41 killed and 107 injured). The biggest attacks in the following years were: the suicide attack in Saint Petersburg underground on 3 April 2017 organised by a group of immigrants from Central Asia (15 killed, over 50 injured), the bombing in Perekrestok supermarket in Saint Petersburg on 27 December 2017, probably done by a mentally ill Russian man 
(18 injured people, including 9 who required hospitalisation), the shooting and bomb attack at a secondary school in Kerch, Crimea ${ }^{20}$ on 17 October 2018, by a student ( 21 people killed — including the perpetrator, 67 injured). As can be seen with these few examples of big-scale attacks, terrorism in Russia is gradually losing its North Caucasian character and increasingly often becomes the domain of radical or mentally instable Russian citizens, or representatives of non-Caucasian nationalities.

Further development of the socio-political situation in the North Caucasus remains an open issue. Statistical decrease in the number of terrorist attacks is definitely too little to state that the region's problems, including security issues, belong to the past. The fighters have disappeared, but what has remained is the factors of radicalisation among young people: on individual, group and macrosocial level ${ }^{21}$. It is still impossible to declare that the socio-political relations in the North Caucasus have improved and become normal. The Russian counter-terrorism strategy and the occurrence of a "corridor" to the Middle East for fighters, have resulted in the fall of direct terrorist threat, but they have not eliminated the sources of terrorism. As a consequence, Russia and the whole international environment, must still look with concern at the North Caucasus, and one of the most current threats native to this region is the possible return of foreign fighters from the Middle East to the post-Soviet lands.

\section{Threat from the Islamic State}

The Islamic State, weakening and falling under the blows of the antiterrorist coalition, faced the need to develop a strategy that would allow jihad to continue under new conditions. As analysts indicate, the battle was to be continued in three forms:

1. By using militant groups loyal to the caliphate, spread across the globe. After proclaiming an Islamic caliphate in Syria and Iraq in June 2014, ISIS officially established 25 provinces in 11 more countries on different continents. Of course, those were also the regions where there had been conflicts and insurgencies long before. These 25 official provinces were voluntarily joined by 23 armed groups in the following years, which gave a total of 48 ISIS provinces in the world.

2. By using FTF returning to their countries, in external operations, including organisation of terrorist attacks.

20 Ukrainian territory annexed and controlled by Russia.

21 Cf: Е. Сокирянская, Можно ли предотвратить новые волны радикализаиии на Северном Кавказе, Радикализаиия и ее профилактика в Чечне, Ингушетии, Дагестане и Кабардино-Балкарии, Центр анализа и предотвращения конфмиктов, 2019, р. 1. 
3. Organising attacks by homegrown terrorists, inspired by ISIS recruiters (most often via the Internet) and aided by experienced FTF mentioned in $2^{22}$.

To what extent has this strategy been applied in Eastern Europe? As known from the previous section of the article - there are no longer strong armed groups in the North Caucasus that would be able to inflict significant damages on Russia in guerrilla warfare or in attacks similar to terrorist methods. There are also no such Islamic groups in the South Caucasus and Ukraine. However, as it turns out, Eastern Europe is not free of problems related to foreign terrorist fighters, nor to self-radicalising homegrown terrorists.

\section{Threat from foreign terrorist fighters}

The last decade (2010-2019), in which there were serious conflicts in the Middle East and North Africa, was a period of increased migration of the $\mathrm{FTF}^{23}$. According to different estimates, between 30,000 and $42,000^{24}$ fighters set their foot in Syria and Iraq during the armed conflict $^{25}$. Among various language and nationality sub groups of the FTF fighting in Syria and Iraq, the largest was the group of fighters from the post-Soviet region.

In February 2017, President Vladimir Putin estimated the number of fighters in Syria to be 4,000 ${ }^{26}$. At the end of October 2018, an even bigger number was given by the Russian Minister of Internal Affairs, who stated that the Russian services were keeping track of 5,000 ISIS fighters from Russia27. In case of Azerbaijan, the reported number was

22 K. Cragin, The global ISIS threat in historical context, Pathways to Peace and Security, 2017, No. 1 (52), Special Issue: Addressing Terrorism, Violent Extremism And radicalization (perspectives from Russia and the United States, p. 78.

23 According to the definition that can be found in Uited Nations documents, Foreign Terrorist Fighters are "individuals who travel to a State other than their States of residence or nationality for the purpose of the perpetration, planning, or preparation of, or participation in, terrorist acts or the providing or receiving of terrorist training, including in connection with armed conflict, and resolving to address this threat". As cited in: Resolution 2178 (2014), <https://www.undocs.org/S/RES/2178\%20(2014)>, 29 July 2020.

24 R. Barrett, Beyond The Caliphate: Foreign Fighters and the Threat of Returnees, New York 2017, p. 11; RAN Centre of Excellence, RAN MANUAL: Responses to returnees: Foreign terrorist fighters and their families, <https://ec.europa. eu/home-affairs/sites/homeaffairs/files/ran_br_a4_m10_en.pdf>, 29 July 2020.

25 Cf. O. Wasiuta, S. Wasiuta, P. Mazur, Państwo Islamskie ISIS. Nowa twarz ekstremizmu, Warsaw, 2018, pp. 141-195.

26 Ведомости, Путин назвал число россиян, воюющих на стороне боевиков в Сирии, <https:/ /www.vedomosti.ru/politics/news/2017/02/23/678892-putin-nazval-chislo-rossiyan>, 29 July 2020.

27 Интерфакс, Пять тысяч россиян уехали из страны и примкнули $\mathrm{K}$ "Исламскому государству", <https://www.interfax.ru/russia/635527>, 29 July 2020. 
approximately $1,000 \mathrm{FTFs}^{28}$. In case of Georgia - up to $200 \mathrm{FTFs}^{29}$. Additional 100 FTF were said to come from Crimea ${ }^{30}$.

Approximately 5,500 ISIS and Al-Qaeda fighters active in the Middle East were from the Central Asia and they must be mentioned here, as they are potentially as dangerous to the Eastern Europe as the FTFs from Russia or South Caucasus (if only due to the presence of a large diaspora of Central Asian nations in Russia). According to reliable estimates, 2,000 Uzbeks, 1,300-2,000 Tajiks, 850 Kirghizs, 500-600 Kazakhs and 360 Turkmen ${ }^{31}$ came to Syria and Iraq. Thus, it is to be estimated that Syria and Iraq became the destination of between 10,000 to 12,000 Russian-speaking FTFs ${ }^{32}$.

Currently, the biggest issue is the behaviour of terrorists after the liquidation of the ISIS in Syria and Iraq. The last wave of returning FTFs included the most radical and jihadist terrorists that managed to survive and avoid prison (fighters disappointed or conflicted with ISIS left the region earlier). In this context, the answer must be found to four fundamental questions found below.

1. How many Russian-speaking FTFs managed to avoid death and capture in the Middle East? It is very difficult to obtain accurate data of how many FTFs in total, as well as Russian-speaking FTFs were killed in the fightings in Syria and Iraq. We can only quote general estimates

28 D. Lonardo, The Islamic State and the connections to historical networks of Jihadism in Azerbaijan, [in:] J. Ratelle, L. Broers (Eds), Networked Insurgencies and Foreign Fighters in Eurasia, New York 2018, p. 138.

29 B. Clifford, Georgian Foreign Fighter Deaths in Syria and Iraq: What Can They Tell Us about Foreign Fighter Mobilization and Recruitment?, Caucasus Survey 2018, Vol. 6, Issue 1, p. 62-80; E. Pokalova, Georgia, Terrorism, and Foreign Fighters, Special Operations Journal, 2018, Vol. 4, Issue 2, p. 146.

30 R. Ehrenfeld, Crimean Tatars and Jihad, <https://acdemocracy.org/thecrimean-tatars-and-jihad/>, 29 July 2020.

31 N. Soliev, Central Asia: Kazakhstan, Kyrgyzstan, Tajikistan, Turkmenistan, Uzbekistan, Counter Terrorist Trends and Analyses, 2019, Vol. 11, Issue 1, p. 65.

32 Among numerous impediments making it impossible to estimate the precise number of FTFs and compounding the confusion, there is also such a problem that the current wave of FTFs includes a large percentage of women and children (usually, the reports give the number of $25 \%$ ). Due to natural causes, this ratio was changing in Syria and Iraq: men would die in combat, women would bear children. As a consequence, we might have a situation, like in the case of Kazakh FTFs, where - according to official reports of 2018 - the total number of approx. 800 people included: 120 men, over 250 women and as many as 500 minors. This changes the picture of threat from their side, but definitely does not eliminate it. Women among the FTFs were often involved in processes of recruiting and indoctrinating fighters, as well as prepared for conducting terrorist attacks. Children, on the other hand, are severely traumatised, indoctrinated, and have been prepared for armed combat and other violent actions since their $9^{\text {th }}$ birthdays. Cf: Радио АЗАТТЫК, Сколько казахстаниев находится за решеткой в Сирии и Ираке?, <https://rus.azattyq.org/a/kazakhstan-siriya-knb-otvet/29401029.html>, 29 July 2020. 
or establishments related to other regions and countries, and then use analogy to attempt at determining the number of Russian-speaking FTFs killed.

In July 2019, Julian King, European Commissioner for the Security Union informed, that out of the total number of 5,500 FTFs from the $\mathrm{EU}$, there were $1,400^{33}$ killed, i.e. approximately $25 \%$. Countries, whose citizens constituted a smaller (and more easily quantifiable) "contingent" of the FTFs, i.e. Western Balkans countries, have more precise data ${ }^{34}$. There are estimates from Azerbaijan, according to which ca. 30\% FTFs were killed (300 per 1,000) ${ }^{35}$. The proportion of the killed usually falls within the range of $14-30 \%$ of the FTFs from a given national or regional group, whereas the values based on the data from the biggest groups (EU, Azerbaijan) speak of $25-30 \%$ killed. Thus, we can say with a high degree of probability, that ca. 25\% of Russian-speaking FTFs, i.e. between 2,500 to 3,000, were killed in Syria and Iraq.

Another group of FTFs that has been "excluded" from further activity, comprises individuals who have been put in prison. According to UN report, in February 2019, there were 1,000 FTFs in prisons within the territory of Iraq, and additional 1,000-1,500 FTFs - in the prisons of NorthEast Syria $^{36}$. The number of the imprisoned was constantly increasing as well. Assuming that there had been ca. 40,000 FTFs in the region of combat operations, it can be calculated that approx. $6 \%$ of them were imprisoned. The same percentage in case of Russian-speaking FTFs translates into about 600-720 fighters put in local prisons.

In summary, it can be estimated that ca. 3,100-3,700 Russian-speaking FTFs were killed or imprisoned. Thus, no less than ca. 6,500 Russianspeaking FTFs managed to survive and preserve their freedom throughout the whole period of the conflict. Very few of them can, in some limited way, continue the fight in Syria (they are the so-called remainers). A vast majority of them managed to leave the combat region.

33 Euobserver, 2,500 foreign terrorist fighters 'unaccounted for', <https://euobserver.com/tickers/145534>, 29 July 2020.

34 According to available information, 14\% FTFs from Albania (20 to 140 in total), 29\% FTFs from Bosnia and Herzegovina (70 to 240), 17\% FTFs from Macedonia (25 to 140-150), 18\% FTFs from Kosovo (58 to 316), 25\% FTFs from Montenegro (5 to 20) and 26\% FTFs from Serbia (11 to 42) were killed between 2012 and 2016. After: V. Azinović, Between Salvation and Terror: Radicalization and the Foreign Fighter Phenomenon in The Western Balkans, Sarajevo 2017, p. 10. Slightly different data are given by: A. Metodieva, Balkan Foreign Fighters Are Coming Back: What Should Be Done?, 2018, p. 5, <https://stratpol.sk/ wp-content/uploads/2018/01/Metodieva_Returnees_Western_Balkans_Stratpol_FINAL.pdf>, 9 June 2020.

35 N. Kamilsoy, Dealing with returning foreign fighters in Azerbaijan: reintegration for de-radicalization?, Praha 2018, p. 5.

36 United Nations, Eighth report of the Secretary-General on the threat posed by ISIL (Da'esh) to international peace and security and the range of United Nations efforts in support of Member States in countering the threat, <https://undocs.org/en/S/2019/103>, 29 July 2020. 
2. In what geographical directions do other FTFs at large move? Basically, they have three directions to choose from - naturally, if physically and formally possible: returning to their countries of origin (so-called returnees), moving to other conflict zones and continuing direct fightings (relocators), going to a third country and stopping fighting or undertaking a clandestine activity (also relocators) ${ }^{37}$. The available data allow to state that only a small percentage of Russian-speaking FTFs decided to go back to their countries. At the end of 2015, Alexander Bortnikov, Director of the Russian Federal Security Service informed that out of the total number of 2,900 ISIS fighters from Russia, 214 returned to the country, which constitutes $7.3 \%{ }^{38}$ A similar percentage is given by a year older (2016) American report stating that out of the total number of 3,417 fighters from Russia, ca. 400 returned to their country of origin - which constitutes ca. $11 \%{ }^{39}$.

For comparison, The United Kingdom made it public that out of 850 ISIS volunteers from this country, as many as $50 \%$ returned by the end of $2015^{40}$. Scandinavian countries have similar indices. Whereas as far as the whole EU is considered, according to mid-2019 reports, out of the whole number of ca. 5,500 FTFs from Europe, 1,600 people returned to their countries ${ }^{41}$ - which constitutes $29 \%$ of them. The aforementioned European Commissioner for the Security Union, J. King also said that EU Member States were still unable to locate 2,500 fighters from Western Europe, and the authorities had no information about their whereabouts $^{42}$.

In view of the above, it must be concluded that returning to their countries is the least chosen option among Russian-speaking FTFs from Eastern Europe. Of course, it results from the fear of repressive measures that might be very severe, for instance in autonomous North Caucasus republics. Going to a third country, or directly to a new conflict zone (Libya, North Sinai, Sahel region, Afghanistan) seems much more rational. However, it should be stated, that for the FTFs from a post-Soviet country the "third country" could be another post-Soviet country might, e.g. Russia for a fighter from Central Asia, Ukraine or Georgia for a fighter from Russia. The choice of moving direction between these two options (a third country or a region of a new conflict) might depend on objective conditions

37 E. Ragab, Returning Foreign Terrorists: What Type of Security Challenges Are They Posing?, IEMed Mediterranean Yearbook 2018, p. 88-91.

38 ITAR-TASS News Agency, ФСБ: на Северном Кавказе из 26 иидеров бандгрупп, присягнувших ИГ, нейтрализовано 20, <https://tass.ru/proisshestviya/2528221>, 29 July 2020.

39 R. Barrett, Beyond..., p. 10.

40 HM Government, CONTEST: The United Kingdom's Strategy for Countering Terrorism: Annual Report for 2015, 2016, p. 7, <https://assets.publishing.service.gov.uk/government/uploads/system/uploads/attachment_data/ file/539683/55469_Cm_9310_Web_Accessible_v0.11.pdf>, 9 June 2021.

41 Euobserver, 2,500 foreign..., op. cit.

42 Ibidem. 
(e.g. impossibility to cross the border due to formal reasons, the fighter's health condition), as well as more subjective ones (personal predisposition, being faithful to the IS orders and its new strategy). It is difficult to determine which of these options is more attractive for Russianspeaking FTFs. Media have already reported that dangerous fighters had appeared in third countries (e.g. in Ukraine - more on this topic further in the article), as well as on new jihad fronts - e.g. in Afghanistan, where, according to the Russian Ministry of Foreign Affairs ${ }^{43}$, there had been a new concentration of fighters, within the so-called Khorasan Province. However, it seems that the majority of surviving FTFs chose third countries and tried to normalise their lives, at least temporarily, while waiting for further development of the situation. What makes it somehow easier for them is the fact that many of them worked or studied in Middle East countries before the outbreak of the Syrian conflict.

3. What is the attitude of the Russian-speaking FTFs to jihadi ideology and will they want to continue the fight? Certainly, many a people who had decided to go to the Middle East, were disappointed with what they found there, did not agree with the self-proclaimed caliphate's drastic methods of action, could not adapt to local conditions, or had a conflict with ISIS and eventually broke with radical Islamism. However, such people, usually very young, probably left Syria already in 2014-2015. In case of Russian-speaking FTFs, we are arguably talking about - more or less - the same people who decided to go back to their countries, i.e. some $7-11 \%$ of Russian-speaking fighters.

There is also a possibility that the FTFs who went to third countries, try to start their lives anew and undergo a process of self deradicalisation. There are also such reports about some FTF groups, but it is hard to refer to specific data or examples. What comes into play in this case is not the renouncement of radical ideology, but rationally-planned cessation of fighting. It should be stated that in spite of former FTFs' genuine efforts, it might be difficult for them to break with the past, as they are threatened with repressive measures, they suffer from health problems (physical and mental), and have aggressive and violent tendencies. All of these are factors that favour renewed radicalisation, and in consequence - renewed involvement in armed combat and terrorism, shall favourable circumstances occur.

4. What kind of terrorist activity will Russian-speaking FTFs undertake, if they want to continue being involved in jihad? Based on Kim Cragin's ${ }^{44}$ and Jeanine de Roy van Zuijdewijn's ${ }^{45}$ typologies, we can list the following types of returning FTFs, who decide to continue fighting:

43 РИА Новости, МИД назвал наиболее чувствительный для России вопрос в обцасти антитеррора, <https://ria.ru/20180703/1523891641.html>, 29 July 2020.

44 K. Cragin, The global..., op. cit., p. 86-87.

45 J. de Roy van Zuijdewijn, The Foreign Fighters' Threat: What History Can (not) Tell Us, Perspectives on Terrorism, 2014, Vol. 8, Issue 5, p. 63-64. The researcher names two more FTF types: "martyr" - whose death is used for propa- 
Veterans - experienced fighters, who continue the combat in different conflict arenas. Jihad is their way of life. Veterans are a threat in conflict zones, but not in their countries of origin (unless there is a war there).

a) Recruiters - usually former FTFs, who returned to their countries to recruit others to fight. They enjoy respect thanks to their past experience in fighting and usually become spiritual leaders for future terrorists. They operate through personal contact or social media.

b) External operatives or simply terrorists - individuals directly involved in preparing and conducting terrorist attacks in their countries of origin or in third countries. They constitute the most direct and biggest threat.

c) Logisticians - individuals who support terrorists conducting attacks in terms of organisation and materials.

d) Leaders and trainers - individuals, who after returning to their countries or going to third countries, joined other combat groups, or even established their own groups and/or training camps for new fighters.

It is very difficult to obtain accurate data related to the number of returnees in Eastern Europe region. Russia informed that ca. 7-11\% of local FTFs (i.e. ca. 400-500 people) returned to the country. There are reports saying that a part of them have re-joined the North-Caucasian underground and undertaken terrorist activity ${ }^{46}$. However, it seems that: 1) among the FTFs returning to Russia, there were many people who want to reintegrate with the society and voluntarily submit themselves to trials and sentences, 2) Russian services are highly efficient in neutralising the threat from the returnees, both during the stage of identification, as well as countering terrorist acts on their side. In case of regions other than the post-Soviet countries, the analyses indicate that FTFs were responsible for conducting: $35 \%$ of attacks in the West, $36 \%$ attacks in the Middle East (outside the ISIS territory) and 20\% attacks in Asia ${ }^{47}$. Russia and Azerbaijan managed to avoid this scenario and prevent the Islamic State from implementing its strategy within their own territories.

Much bigger - not recognised completely yet - is the threat from relocators, who decided to return to the post-Soviet region, but not to their countries. The key role in this respect is unfortunately played by the Ukrainian territory. Open and independent Ukrainian sources

ganda purposes, as well as an "reintegrated fighter" - disappointed with fighting in the conflict zone, often motivated by factors different than religion, who returns to normal life after going back to their country of origin (this type was discussed above).

46 РИА ДАГЕСТАН, НАК: в Дагестане нейтрализованы два бандглаваря и боевик, вернувшийся из Сирии, <https://www.riadagestan.ru/news/inciden ts/nak_v_dagestane_neytralizovany_dva_bandglavarya_i_boevik_vernuvshiys уа_iz_sirii/>, НАК: в Дагестане нейтрализованы два бандглаваря и боевик, вернувшийся из Сирии, <https://www.riadagestan.ru/news/incidents/nak_v_d agestane_neytralizovany_dva_bandglavarya_i_boevik_vernuvshiysya_iz_sirii/>, 29 July 2020.

47 K. Cragin, The global..., op. cit., p. 78. 
of information for months mentioned the presence of Russian-speaking FTFs around the whole country. The possible reasons for this are: similarity of languages, ease of obtaining forged documents in Ukraine to move without much hindrance to other countries, the conviction that Ukraine will not extradite arrested FTFs to their countries of origin (mainly Russia), Ukrainian people's neutral attitude towards Muslims. What made it much easier for the FTFs, was the formal and legal arrangements between Turkey and Ukraine, which enabled the fighters captured by Turkish services to choose Ukraine as their deportation destination ${ }^{48}$. As for forging documents, it is the territory of Crimea that plays the negative role. There are criminal groups there, who can issue false Ukrainian documents practically to anyone, including Jihadists wanted by the International Criminal Police Organisation (Interpol). Similar groups operated in the oblast of Kharkov, Kiev and Dnipropetrovsk ${ }^{49}$. Already in 2017 , <https://hromadske.ua> website estimated that at least several hundred jihadi relocators from ISIS used this route to get to Ukraine. Confirmation of the most disturbing estimates came in November 2019, when the combined efforts of the Security Service of Ukraine (SBU), Interpol and Georgian Home office led to the arrest of Abu-Bara al-Pankisi (born Caesar Tohosashvili, also known as Levan) - one of the main ISIS leaders (the caliphate's "minister of war" after the death of the famous Abu-Umar alShishani, born Tarkhan Batirashvili). Abu-Bara al-Pankisi got to Ukraine in 2018. Using forged documents, he legalised his stay, and staying close to Kiev, coordinated the activity of terrorist cells that were subordinate to him ${ }^{50}$. It is unclear what Abu-Bara's exact plans were, but arresting such a high-rank ISIS terrorist - despite being SBU's unquestioned success and the proof that cooperation with other countries' services goes well - makes one conclude that the presence of FTFs in Ukraine is currently one of the biggest threats related to Islamic terrorism in the whole region of Eastern Europe.

\section{Homegrown terrorists in Eastern Europe}

Another threat is posed by the so-called homegrown terrorists, i.e. people who are to varying extents inspired by ISIS activity and propaganda, as well as their own religious beliefs, but not controlled directly by any

48 К. Сергацкова, На пути из ИГИА: как бывшие боевики "Исламского государства" оказываются в Украине, <https://hromadske.ua/ru/posts/ na-puty-yz-yhyl-kak-byvshye-boevyky-yslamskoho-hosudarstva-okazyvaiutsia-v-ukrayne>, 29 July 2020.

49 А. Приймак, В Киеве обеспокоены "черной паспортизаиией" meppopucmoв, <http://www.ng.ru/ng_religii/2019-12-03/13_477_ukraine.html>, 29 July 2020.

50 К. Сергацкова, Террорист с близкого расстояния. Как один из лидеров "Исламского государства" оказался в Украине, <https://hromadske.ua/ru/ posts/terrorist-s-blizkogo-rasstoyaniya-kak-odin-iz-liderov-islamskogo-gosudarstva-okazalsya-v-ukraine>, 29 July 2020. 
foreign terrorist centres. Such individuals, or very small groups, appear in particular in Russia. The aforementioned attack of 3 April 2017 in Saint Petersburg underground was carried out by a group of at least 11 people from Central Asia (Kyrgyzstan, Uzbekistan, Tajikistan). The main organisers were probably: 29-year-old Abror Azimov - a Kirghiz with Russian citizenship - and his 31-year-old brother Akram Azimov (responsible for international telecommunications). The instigator was a Kirghiz Islamist staying in Syria, Sirojiddin Mukhtarov (Abu Salah alUzbeki). Whereas the direct executor was a 22-year-old suicide bomber Akbarjon Djalilov - also a Kirghiz with Russian citizenship. Before that, for a year (from the end of 2015 to December 2016), Djalilov was in Aleppo, at Mukhtarov's training centre, where he must have learned the skill of using explosives. Having returned, he took part in direct preparations under the supervision of Abror Azimov for a month, and then he conducted the attack killing 15 and leaving over 50 injured ${ }^{51}$. This example shows the whole mechanism of an attack of this type: local terrorists, acting out of inspiration and with a limited support from foreign centres (which in this case constituted the training of the direct executor of the future, unspecified attack) managed to avoid being smashed by Russian services and conduct a bloody assault in one of Russia's biggest metropolises. It also proves that there has been a rise of terrorist threat from Central Asia radicals in the past years.

Another example of homegrown terrorism is the foiled attack that a group of ethnic Russians planned to conduct on New Year's Day 2020 in Saint Petersburg shopping centres. The group contacted the inspirers from the ISIS through Internet tools and consulted potential attack spots. These contacts were discovered by American intelligence, which warned the Russian security service in time (later Vladimir Putin thanked Donald Trump on the phone). The group was broken a few days before the planned attack, but we do not know what might have happened, had it not been for the USA's help ${ }^{52}$. A similar situation took place in 2017, when the Americans helped to prevent the attack on the Kazan Cathedral in Saint Petersburg. Then, the attack was organised by a group made of two ethnic Russians, one person from Dagestan, one Ingush and one Tajik $^{53}$.

FSB statistics indicate that new cells of this type appear in Russia relatively often, particularly in big cities. According to Russian services,

51 М. Аеонов, "Сопротивляется, впадает в истерику". Суд в Петербурге закониил исследование доказательств по делу о теракте в метро, <https: / / novayagazeta.ru/articles /2019/11/19/82790-soprotivlyaetsya-vpadaet-v-ister iku>, 29 July 2020.

52 Интерфакс, ФСБ предотвратила теракт в Петербурге благодаря сигналу от спеислужб США, <https://www.interfax.ru/russia/689826>, 29 July 2020.

53 Интерфакс, Российские спеислужбы предотвратили теракты в Петербурге благодаря данным ЦРУ, <https://www.interfax.ru/russia/592199>, 29 July 2020. 
only during the first 10 months of 2019, 32 fighters were eliminated, 679 people arrested, and 22 "coaxed into quitting" terrorist activity. In total, 49 terrorist cells were smashed, 5,500 people suspected of connections with illegal groups had their accounts blocked, and access to ca. 8,000 websites of a "destructive influence" was blocked" 54 . These data show how wide a scope of activities is undertaken by Russian secret service in terms of fighting terrorism and how big the scale of this threat is.

\section{Conclusion}

With reference to the main research question asked in the introduction of this article, it should be concluded that Islamic terrorism affects the level of security of most East European countries. It poses the biggest threat to Russia, which has a big population of Muslims, migrants, and hostile ethnic groups (e.g. in the North Caucasus) in its territory, big urban agglomerations, where it is easy to launch an attack, and which conducts a very active policy in the Middle East. The threat of Islamic terrorism is relatively high here, but the last large-scale attack took place back in 2017 , and before that in 2013. Russian services conduct a very active anti-terrorist policy, which certainly brings direct effects, as proven by the elimination of potentially dangerous terrorist cells and preventing massive attacks. In other countries, such as Azerbaijan, Georgia or Ukraine, the threat of Islamic terrorism is connected with foreign terrorist fighters that used to fight in the ISIS and with their potential further terrorist activity. However, based on foregoing experience, it seems that secret services of those countries are able to neutralise this threat. In countries such as Armenia, Belarus or Moldova, the problem of Islamic terrorism does not occur in practice.

With reference to specific research questions established at the beginning, it should be concluded that:

1) As generally understood, terrorism poses varying degrees of threat to different countries of Eastern Europe. In case of countries such as Belarus, Moldova or Armenia, it constitutes a marginal phenomenon (due to effective anti-terrorist policy, lack of motives for launching attacks, lesser psychological effects on the international scale related to potential attacks). Ukraine faces much bigger terrorism issues, mainly due to the "hybrid" conflict in the east of the country, or radicalisation of certain circles. What is involved here are separatist, nationalist, and in some cases also state terrorism, i.e. inspired, supported or at least tolerated by two conflicted countries. All of this explains the reason why terrorism index is the highest in Ukraine. In case of South Caucasus countries, there is a visible process going in a different direction: separatist, nationalist and inter-political terrorism gives way to Islamic terrorism. As far as Russia is concerned,

54 РИА Новости, Российские спеислужбы предотвратили 39 терактов в 2019 годy, <https://ria.ru/20191016/1559839755.html>, 29 July 2020. 
the main threat is invariably the Islamic terrorism. A positive tendency is a slow, but stable in the last years, decrease in terrorism index in two biggest countries: Russia and Ukraine.

2) North-Caucasian terrorism has undergone a significant evolution in the last decade. In the peak period, ca. 2010, local attacks and bombings led to a great number of victims. Terrorists carried out successful attacks also in central Russia. However, in the following years, ruthless Russian actions (eliminating fighters, mass repressions etc.) became an effective deterrent factor, and the region's potential new fighters were abstracted by the conflict in the Middle East. The conflict's intensity in the region decreased significantly, North-Caucasian terrorism became more scattered, globalised, and more connected with the Middle East. However, the security of the North Caucasus region itself remains an open issue, as there are still many conflict-triggering factors there.

3) Foreign terrorist fighters and their activities are currently one of the biggest threats and challenges on the international level. It is highly likely that they will continue their terrorist activities in new places. It seems that most Russian-speaking FTFs will stay in the Greater Middle East region (apart from Syria), mainly in Turkey, or move to one of the postSoviet countries (other than the country of origin), to try to go back to normal life, at least temporarily. All East European countries conduct intensive activities aimed at neutralising the threat from the FTFs, which so far has brought better results than, for instance, in Western Europe. From the point of view of Central Europe's security, the presence of FTFs in Ukraine, which has a visa-free regime with the EU, is a dangerous phenomenon. Direct threat of attacks comes mainly from homegrown terrorists, radicalised under ISIS influence, difficult to track, as they usually connect with the Middle East only through Internet communication channels. In Russia, thanks to intensive work of the secret service and effective cooperation with foreign partners (mainly American), serious threat from their side is in most cases neutralised. In summary, it can be said that the threat of Islamic terrorism is very much real in Eastern Europe. Much bigger than in Central Europe, for instance, but on a similar level to some West-European countries (France, $\mathrm{UK})$. How the situation in terms of anti-terrorist security develops, will probably depend on many factors. However, what seems to be most important, is to sustain the determination and cooperation of all the region's countries in fighting the network of terrorist Islamic groups.

\section{References}

\section{Publications}

Aleksandrowicz T.R, Kluczowe megatrendy w bezpieczeństwie państwa w XXI wieku, Warsaw, 2020. 
Azinović V, Between Salvation and Terror: Radicalization and the Foreign Fighter Phenomenon in The Western Balkans, Sarajevo, 2017.

Barrett R, Beyond The Caliphate: Foreign Fighters and the Threat of Returnees, New York, 2017.

Clifford B, Georgian Foreign Fighter Deaths in Syria and Iraq: What Can They Tell Us about Foreign Fighter Mobilization and Recruitment?, Caucasus Survey, 2018, Vol. 6, Issue 1.

Cragin K, The global ISIS threat in historical context, Pathways to Peace and Security, 2017, No 1 (52), Special Issue: Addressing Terrorism, Violent Extremism And radicalization (perspectives from Russia and the United States.

Kamilsoy N, Dealing with returning foreign fighters in Azerbaijan: reintegration for de-radicalization?, Praha, 2018.

Lonardo D, The Islamic State and the connections to historical networks of Jihadism in Azerbaijan [in:] Ratelle J., Broers L. (Ed.), Networked Insurgencies and Foreign Fighters in Eurasia, New York, 2018.

Pokalova E, Georgia, Terrorism, and Foreign Fighters, Special Operations Journal, 2018, Vol. 4, Issue 2.

Ragab E, Returning Foreign Terrorists: What Type of Security Challenges Are They Posing?, IEMed Mediterranean Yearbook, 2018.

Roy van Zuijdewijn de J., The Foreign Fighters' Threat: What History Can (not) Tell Us, Perspectives on Terrorism, 2014, Vol. 8, Issue 5.

Soliev N, Central Asia: Kazakhstan, Kyrgyzstan, Tajikistan, Turkmenistan, Uzbekistan, Counter Terrorist Trends and Analyses, 2019, Vol. 11, Issue 1 .

Wasiuta O, Wasiuta S., Mazur P., Państwo Islamskie ISIS. Nowa twarz ekstremizmu, Warsaw, 2018.

Гикашвими Г, Терроризм на Южном Кавказе, „Постсоветские исследования" 2019, Vol. 2, No. 5.

\section{Other sources}

Ehrenfeld R, Crimean Tatars and Jihad. Electronic source: https://acdemocracy.org/the-crimean-tatars-and-jihad/

Euobserver, 2,500 foreign terrorist fighters 'unaccounted for'. Electronic source: https: / / euobserver.com/tickers / 145534

HM Government, CONTEST: The United Kingdom's Strategy for Countering Terrorism: Annual Report for 2015, 2016. Electronic source: https:/ / assets.publishing.service.gov.uk/government/uploads/system/uploads /attachment_data/file/539683/55469_Cm_9310_Web_Accessible_v0.11.pdf

Institute for Economics \& Peace, Global Terrorism Index 2014: Measuring and understanding the impact of terrorism, Sydney 2014.

Institute for Economics \& Peace, Global Terrorism Index 2015: Measuring and understanding the impact of terrorism, Sydney 2015.

Institute for Economics \& Peace, Global Terrorism Index 2016: Measuring and understanding the impact of terrorism, Sydney 2016. 
Institute for Economics \& Peace, Global Terrorism Index 2017: Measuring and understanding the impact of terrorism, Sydney 2017.

Institute for Economics \& Peace, Global Terrorism Index 2018: Measuring the impact of terrorism, Sydney 2018.

Institute for Economics \& Peace, Global Terrorism Index 2019: Measuring the Impact of Terrorism, Sydney 2019.

ITAR-TASS News Agency, ФСБ: на Северном Кавказе из 26 мидеров бандгрупп, присягнувших ИГ, нейтрализовано 20. Electronic source: https://tass.ru/proisshestviya/252822 1

Metodieva A, Balkan Foreign Fighters Are Coming Back: What Should Be Done?, 2018. Electronic source: https://stratpol.sk/wp-content/uploads/2018/01/ Metodieva_Returnees_Western_Balkans_Stratpol_FINAL.pdf

RAN Centre of Excellence, RAN MANUAL: Responses to returnees: Foreign terrorist fighters and their families. Electronic source: https://ec.europa. eu/home-affairs/sites/homeaffairs/files/ran_br_a4_m10_en.pdf

Sputnik, Борьба с терроризмом в Азербайджане дает свои плоды Кямиль Салимов. Electronic source: https://az.sputniknews.ru/expert/20191106/422236799/azerbaijan-terrorizm-usa.html

Sputnik, Террористы все реже используют Грузию для транзита отчет Службы госбезопасности. Electronic source: https://sputnikgeorgia.ru/georgia/20190422/245015484/terroristy-vse-rezhe-ispolzuyut-gruziyu-dlya-tranzita---otchet-sluzhby-gosbezopasnosti.html

United Nations, Eighth report of the Secretary-General on the threat posed by ISIL (Da'esh) to international peace and security and the range of United Nations efforts in support of Member States in countering the threat. Electronic source: https://undocs.org/en/S/2019/103

United Nations, Resolution 2178 (2014). Electronic source: https://www. undocs.org/S/RES/2178\%20(2014)

United States Department of State Publication, Country Reports on Terrorism 2018, October 2019.

Youngman M, Moore C, Russian-Speaking' Fighters In Syria, Iraq And At Home: Consequences And Context (Full Report), 2017. Electronic source: https://crestresearch.ac.uk/resources/russian-speaking-fighters-full-report

Ведомости, Путин назвац число россиян, воюющих на стороне боевиков в Сирии. Electronic source: https://www.vedomosti.ru/politics/news/2017/02/23/678892-putin-nazval-chislo-rossiyan

ГРУЗИНФОРМ, Правительство Грузии утвердило Наииональную стратегию по борьбе с терроризмом на 2019-2021 годы, разработанную межведомственной комиссией во главе со службой госбезопасности Грузии. Electronic source: http://ru.gruzinform.ge/news/39383/pravitelistvo-gruzii-utverdilo-nacionalinuU-strategiU-po-boribe-s-terrorizmomna-2019-2021-godi-razrabotannuU-meZvedomstvennoj-komissiej-vo-glave-so-sluZboj-gosbezopasnosti-gruzii.html

Интерфакс, Пять тысяч россиян уехали из страны и примкнули к "Исламскому государству". Electronic source: https://www.interfax. ru/russia/635527 
Интерфакс, Российские спеислужбы предотвратили теракты в Петербурге благодаря данным ЦРУ. Electronic source: https: / www. interfax.ru/russia/592199

Интерфакс, ФСБ предотвратила теракт в Петербурге благодаря сигналу от спеислужб США. Electronic source: https:/ /www.interfax. $\mathrm{ru} / \mathrm{russia} / 689826$

Кавказский Узем, Выходиы с Кавказа в рядах ИГ (ИГИА). Electronic source: https://www.kavkaz-uzel.eu/articles/251513/\#cont_3

Кавказский Узел, Северный Кавказ - статистика жертв, Electronic source: https: / /www.kavkaz-uzel.eu/rubric/1103?page=1

Кумей И, Кто устроил теракт в минском метро?, Electronic source: https: / / belsat.eu/ru/programs/kto-ustroil-terakt-v-minskom-metro

Аеонов M, "Сопротивляется, впадает в истерику". Суд в Петербурге закониил исследование доказательств по делу о теракте в метро. Electronic source: https:/ / novayagazeta.ru/articles/2019/11/19/82790soprotivlyaetsya-vpadaet-v-isteriku

Мартиросян Р, Для Армении угрозой терроризма является не ИГИА, а Азербайджан. Electronic source: https://inosmi.ru/politic/20170829/240132450.html

Приймак А, В Киеве обеспокоень "черной паспортизаиией" террористов. Electronic source: http://www.ng.ru/ng_religii/2019-12-03/13_477_u kraine.html

Радио АЗАТТЫК, Сколько казахстанцев находится за решеткой в Сирии и Ираке?. Electronic source: https://rus.azattyq.org/a/kazakhstan-siriya-knb-otvet/29401029.html

РИА ДАГЕСТАН, НАК: в Дагестане нейтрализованы два бандглаваря и боевик, вернувшийся из Сирии. Electronic source: https://www.riadagestan.ru/news/incidents/nak_v_dagestane_neytralizovany_dva_ bandglavarya_i_boevik_vernuvshiysya_iz_sirii/

РИА Новости, МИД назвац наиболее чувствительный для России вопрос в области антитеррора. Electronic source: https://ria.ru/2018 0703/1523891641.html

РИА Новости, Российские спеислужбы предотвратили 39 терактов в 2019 zody. Electronic source: https:/ / ria.ru/20191016/1559839755. html

Сергацкова K, На пути из ИГИА: как бывшие боевики «Исламского государства" оказываются в Украине. Electronic source: https://hromadske.ua/ru/posts / na-puty-yz-yhyl-kak-byvshye-boevyky-yslamskoho-hosudarstva-okazyvaiutsia-v-ukrayne

Сергацкова К, Террорист с близкого расстояния. Как один из лидеров "Исламского государства" оказался в Украине. Electronic source: https:/ / hromadske.ua/ru/posts / terrorist-s-blizkogo-rasstoyaniya-kak-odin-iz-liderov-islamskogo-gosudarstva-okazalsya-v-ukraine

Сокирянская Е, Можно ли предотвратить новые волны радикализаиии на Северном Кавказе, Радикализаиия и ее профилактика в Чечне, Ингушетии, Дагестане и Кабардино-Балкарии, Центр анализа и предотвращения конфмиктов, 2019. 
DOI: $10.5604 / 01.3001 .0015 .2499$

http://dx.doi.org/10.5604/01.3001.0015.2499

Keywords: terrorism, Islam, Foreign Terrorist Fighters, Russia, Ukraine, Caucasus, Islamic State, Syria, Eastern Europe, security

Summary: The article presents the analysis of the threat to the security of Eastern European countries posed by groups and individuals invoking the ideology of radical Islam. Particular attention is given to the region's two biggest countries: Russia and Ukraine. After a general assessment of the terrorist threat in individual countries based on the Global Terrorism Index, the following are analysed: evolution of the terrorism of North Caucasus groups, scale of threat from the Islamic State, and particularly from foreign terrorist fighters (FTFs), as well as examples of homegrown Islamic terrorism in Russia. 